\title{
Detection by Agarose Gel Electrophoresis of Nucleases Associated with Cells and Protoplasts from Plant Supension Cultures Using Agrobacterium tumefaciens Ti Plasmid*
}

\author{
A. Schaefer, ${ }^{* *}$ K. Ohyama ${ }^{\dagger}$ and O. L. GamborG ${ }^{\dagger \dagger}$ \\ National Research Council of Canada, Prairie Regional Laboratory, \\ Saskatoon, Saskatchewan, S7N 0W9, Canada
}

Received December 5, 1980

\begin{abstract}
Nuclease activity associated with cells and protoplasts was analyzed by agarose gel electrophoresis. Datura innoxia protoplasts were found to possess a high exonuclease activity. On the other hand, Datura innoxia cells had an endonuclease activity, but no apparent exonuclease. The exonucleases from the protoplasts were active at $\mathrm{pH} 5$ and 6, but not at $\mathrm{pH} 9$. Endonuclease activity from the cells was also inhibited at pH 9. Cultured cells of Daucus carota, Glycine max, Pisum sativum and Vicia hajastana had endonuclease activity, but did not exhibit exonuclease activity. Nicotiana suaveolens cells had both types of nuclease activity. On the other hand, cells from cereals such as Triticum monococcum, Oryza sativa, and Zea mays had active exonuclease activity.
\end{abstract}

Investigations on genetic modification of plants have been carried out by feeding foreign DNA. ${ }^{1,2)}$ In spite of extensive investigations into the fate of exogenous DNA in plants, the nature and extent of uptake of intact DNA has not been elucidated and remains controversial. ${ }^{3,4)}$ The availability of large quantities of isolated plant protoplasts provides material which is superior to whole plants for DNA uptake studies, particularly because protoplasts lack cell walls which may be a physical barrier for DNA passage into the cells, and because experiments can be readily carried out under aseptic conditions. ${ }^{5,6)}$ Feeding foreign DNA is often complicated by donor DNA degradation by nucleases associated with plant cells. ${ }^{7,8)}$ An alternative may be the use of a vector comprised of plant pathogenic DNA,

\footnotetext{
* NRCC Number 19291.
}

** Visiting scientist supported by NATO Research Fellowship, present address: Mikrobiologie Universitate Heidelberg, D6900 Heidelberg, West Germany.

$\uparrow$ Present address: Laboratory of Biochemistry, Department of Agricultural Chemistry, Kyoto University, Kyoto 606, Japan.

it Present address: International Plant Research Institute, Inc., 887 Industrial Road, San Carlos, Calif. 94070, U.S.A. e.g. DNA from cauliflower mosaic virus, ${ }^{9)}$ or bacterial plasmid DNA. ${ }^{10}$

The $\mathrm{Ti}$ plasmid from $A$. tumefaciens has been found to be responsible for crown gall tumor formation in dicotyledonous plants. ${ }^{11,12)}$ After infection a part of the $\mathrm{Ti}$ plasmid is incorporated into the genomes of the plant cells which then become tumorous. ${ }^{13}$ ) This might suggest that the Ti plasmid DNA is protected in some manner against extensive degradation by nucleases of the host cells. Few investigations have been reported on nucleases in DNA uptake systems. Bendich and Filner, ${ }^{7)}$ and Hotta and Stern ${ }^{8)}$ reported the occurrance of extensive degradation of foreign. DNA added to plant cells. Suzuki and Takebe, ${ }^{14)}$ and Hughes et al $^{15)}$ also reported a considérable degradation of exogenous DNA when protoplasts were used. We also reported preliminary results on plasmid DNA uptake by Datura innoxia protoplasts. ${ }^{16)}$ In this paper we report on the detection by agarose gel electrophoresis of nuclease activity associated with cells or protoplasts using $A$. tumefaciens Ti plasmid DNA. 


\section{MATERIALS AND METHODS}

Cell culture and preparation of protoplasts. Cell suspension lines in the logarithmic phase of growth were used from the following species: carrot (Daucus carota), tobacco (Nicotiana suaveolens), soybean (Glycine max), wheat (Triticum monococcum) grown in 1-B5 medium, ${ }^{17)}$ pea (Pisum sativum) and rice (Oryza sativa) grown in $1-\mathrm{B} 5 \mathrm{C}$ medium, ${ }^{17)}$ Datura innoxia grown in $1-\mathrm{M} 51 \mathrm{C},{ }^{18)}$ vetch (Vicia hajastana) grown in 0.5-ER medium, ${ }^{197}$ and corn (Zea mays) grown in a medium consisting of equal volumes of 2-ER and 2-B5C media. The cells were washed two times with $0-\mathrm{M} 51 \mathrm{C}$ medium. Protoplasts of Datura cells were prepared under sterile conditions by incubation of equal volumes of cell suspension and enzyme solution in the dark at room temperature for $2 \sim 4 \mathrm{hr}^{20)}$ The enzyme solution consisted of $1 \%$ Driselase, $0.5 \%$ pectinase, $0.1 \mathrm{~g} / \mathrm{ml}$ sorbitol, $0.9 \mathrm{mg} / \mathrm{ml} \quad \mathrm{CaCl}_{2} \cdot 2 \mathrm{H}_{2} \mathrm{O}, 0.1$ $\left.\mathrm{mg} / \mathrm{ml} \mathrm{CaH} \mathrm{COO}_{4}\right)_{2} \cdot \mathrm{H}_{2} \mathrm{O}, \mathrm{pH}$, 5.5. Protoplasts were washed 3 times with $0-\mathrm{M} 51 \mathrm{C}$ medium containing $0.275 \mathrm{M}$ sorbitol, and then suspended in the same medium.

Preparation of Ti plasmid DNA. Plasmid DNA from the virulent $A$. tumefaciens strain Ach 5 (obtained from Dr. J. Schell, Belgium) was prepared according to Ledeboer $e t$ $a l .^{21)}$ After the second CsCl-ethidium bromide (EtBr) centrifugation the lower band, consisting mainly of closed circular plasmid DNA, was collected and the EtBr was removed by gentle shaking with saturated CsClisopropanol. After dialysis against TE $(0.05 \mathrm{M}$ Tris- $\mathrm{HCl}$, $0.02 \mathrm{M}$ EDTA, pH 8) buffer plasmid DNA was stored at $-20^{\circ} \mathrm{C}$.

Determination of nuclease activity. The standard incubation mixture had a total volume of $200 \mu$ consisting of $100 \mu \mathrm{l}$ of cell suspension ( $1 \sim 4 \mathrm{mg} \mathrm{dry}$ weight $/ \mathrm{ml}$ ), protoplast suspension (approximately $6 \times 10^{6}$ protoplasts $/ \mathrm{ml})$, or protoplast supernatant, $40 \mu \mathrm{l}(1 \mu \mathrm{g})$ of DNA solution, $20 \mu 1$ of $0.05 \mathrm{M}$ potassium phosphate buffer $(\mathrm{pH} \mathrm{6}), 20 \mu \mathrm{l}$ of $1 \mathrm{M}$ sorbitol, and $20 \mu \mathrm{l}$ of $\mathrm{H}_{2} \mathrm{O}$. For nuclease analysis of protoplast supernatant, the protoplast suspension was centrifuged at $300 \times g$ for $3 \mathrm{~min}$ and the resulting supernatant used. After incubation at $22^{\circ} \mathrm{C}$ for $1 \mathrm{hr}$ the protoplasts or cells were pelleted by centrifugation $(300 \times g, 3 \mathrm{~min})$ and the DNA in the supernatant analyzed by electrophoresis on $0.35 \%$ agarose slab gels $(2 \sim 4 \mathrm{hr}, 50 \mathrm{~mA})$. Electrophoresis buffer consisted of $0.04 \mathrm{M}$ Tris-acetate, $0.005 \mathrm{M}$ sodium acetate, $0.001 \mathrm{M}$ EDTA, EtBr $(1 \mu \mathrm{g} / \mathrm{ml})$, pH 7.8. Agarose gels $(0.35 \%$, $\left.14 \times 14 \times 0.3 \mathrm{~cm}^{3}\right)$ were prepared to electrophoresis buffer. Marker dye was bromophenol blue $(0.1 \%$ in $50 \%$ sucrose, $0.1 \mathrm{M}$ EDTA). Bands were visualized in the dark under $254 \mathrm{~nm}$ UV light and photographed.

\section{RESULTS}

Detection of nucleases in cells and protoplasts from suspension cultures

Preliminary results for plasmid DNA and chromosomal DNA uptake by Datura protoplasts indicated the presence of extremely active nucleases in the protoplast preparation. ${ }^{16)}$ Therefore, we employed a simple method to detect nuclease activity of cells and protoplasts by using agarose gel electrophoresis. A long smeared band indicates exonuclease activity (e.g., column 1, 2 and 3 in Fig. 1).

Electrophoresis analysis on $0.35 \%$ agarose gels showed that the plasmid DNA preparations have two bands (column 10 in Figs. 1 and 2). The slower migrating band consists of closed circular molecules, while the faster moving band most likely consists of the sheared linear molecules.

When cells from several plant suspension cultures were incubated with plasmid DNA, the slower migrating band in most cases disappeared (Fig. 1). The disappearance of slower migrating band (closed circular plasmid DNA) is believed to be a result of endonuclease activity. Incubation with vetch, pea, Datura,
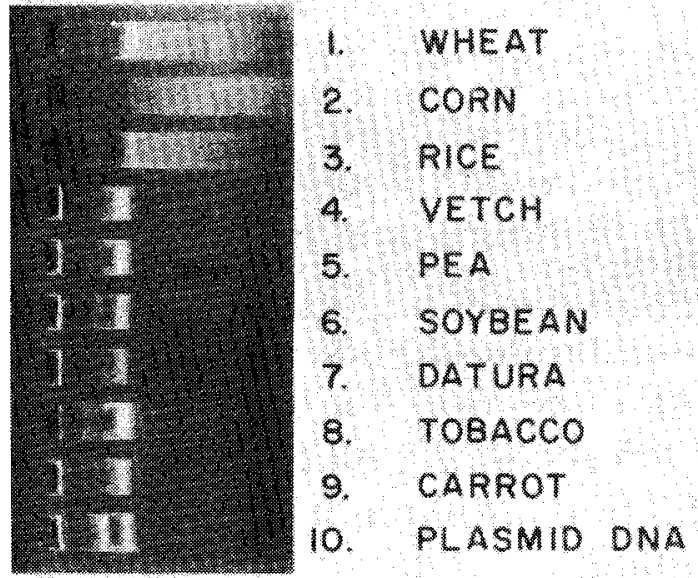

FIG. 1. Agarose Gel Electrophoresis after Incubation of Different Cell Cultures with Plasmid DNA

(1) Triticum monococcum; (2) Zea mays; (3) Oryza sativa; (4) Vicia hajastana; (5) Pisum sativum; (6) Glycine max; (7) Datura innoxia; (8) Nicotiana suaveolens; (9) Daucus carota; (10) plasmid DNA control (note two distinct bands). 


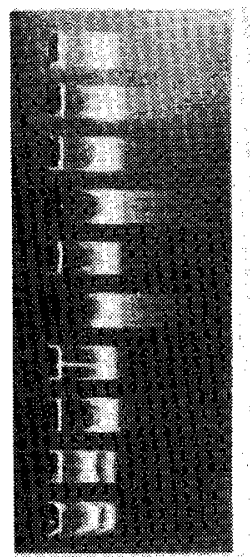

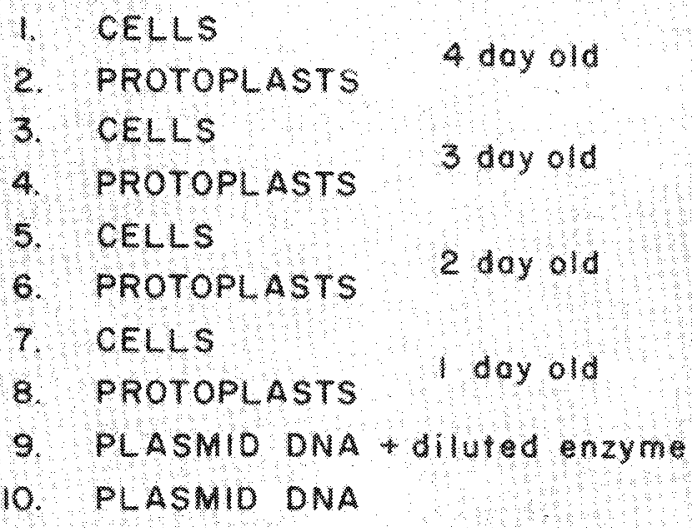

FIG. 2. Agarose Gel Electrophoresis after Incubation of Protoplasts and Cells of Various Ages of Datura innoxia with Plasmid DNA.

(1) 4 day old cells; (2) protopalsts of 4 day old cells; (3) 3 day old cells; (4) protoplasts of 3 day old cells; (5) 2 day old cells; (6) protoplasts of 2 day old cells; (7) 1 day old cells; (8) protoplasts of 1 day old cells; (9) plasmid DNA and diluted enzyme solution (enzyme for preparation of protoplasts); (10) plasmid DNA control.

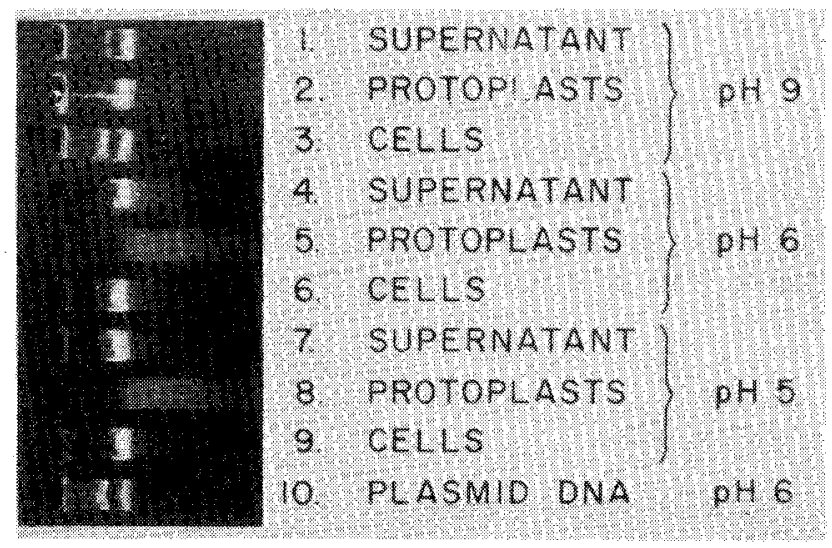

FIG. 3. Influence of $\mathrm{pH}$ on Nuclease Activity from Cells and Protoplasts of Datura innoxia Using Plasmid DNA as Substrate.

(1) the supernatant of protoplast suspension at $\mathrm{pH} \mathrm{9;} \mathrm{(2)} \mathrm{protoplasts} \mathrm{at} \mathrm{pH} 9$; (3) cells at $\mathrm{pH} 9$; (4) the supernatant of protoplast suspension at $\mathrm{pH} 6 ;(5)$ protoplasts at $\mathrm{pH} 6 ;(6)$ cells at $\mathrm{pH} 6 ;(7)$ the supernatant of protoplast suspension at $\mathrm{pH} 5 ;(8)$ protoplasts at $\mathrm{pH} 5 ;(9)$ cells at $\mathrm{pH} 5$; (10) plasmid DNA control at $\mathrm{pH} 6$.

and carrot cells yielded only the fast moving band (Fig. 1, column 4, 5, 7 and 9) indicating only endonuclease activity. In soybean cells a small amount of the slower migrating band was occasionally present (Fig. 1, column 6). The tobacco cells appeared to contain some exonuclease activity because to some extent the smeared pattern can be seen (Fig. 1, column 8). Wheat, corn, and rice cells consistently showed pronounced exonuclease ac- tivity (Fig. 1, column 1, 2, and 3).

Figure 2 shows the effect of age on nuclease activity of Datura cells and the protoplasts. Electrophoresis gel patterns showed only the faster migrating band after incubation with 1 , 2,3 , and 4 day old cells, indicating the presence of endonuclease activity but no exonuclease activity (Fig. 2, column 1,3, 5, and 7). On the other hand, the protoplasts isolated from the same cells have exonuclease activity 
which seemed to be lower with protoplasts from 1 to 4 day old cells (Fig. 2, column 2, 4, 6, and 8 ).

In order to test the influence of $\mathrm{pH}$ on nuclease activity (Fig. 3), slightly modified incubation mixtures were used. Cells and protoplasts were washed with 0 -M51C medium containing $0.275 \mathrm{M}$ sorbitol, then suspended in $0.05 \mathrm{M}$ potassium phosphate buffer at $\mathrm{pH} 5,6$, and 9 , containing $0.275 \mathrm{~m}$ sorbitol. Prior to use the plasmid DNA was dialyzed against $0.05 \mathrm{M}$ potassium phosphate buffer at $\mathrm{pH} 5,6$, and 9 . Exonucleases from protoplasts were active at pH 5 and 6 (Fig. 3, column 5 and 8), but not at pH 9 (column 2). Conversion of the slower migrating band into the faster migrating band (due to endonuclease activity) by Datura cells was observed at pH 5 and 6 (Fig. 3, column 6 and 9), but not at pH 9 (Fig. 3, column 3). When protoplasts were pelleted at low speed centrifugation and the supernatant incubated with plasmid DNA, no significant exonuclease activity was observed (Fig. 3, column 1, 4, and 7). This suggests that the exonuclease activity is associated with the protoplasts and not due to internal nucleases released from broken protoplasts.

\section{DISCUSSION}

We have used agarose gel electrophoresis as a simple method for detecting nuclease activity from plant cells and protoplasts. In this study only the nuclease activity accessible to the substrate is detected, i.e. nuclease activity of the outer surface of cells or protoplasts and free nucleases outside cells or protoplasts.

Cells from several suspension cultures and protoplasts of Datura cells showed two kinds of nuclease activity. All protoplast preparations and especially cell suspensions from monocotyledonous plants had very active exonucleases which extensively degrade DNA. Another nuclease activity, detected with most cells of dicotyledonous plants tested, is likely an endonuclease activity which results in the formation of a single faster migrating band from the slower migrating band.
Electrophoretic analysis revealed that both exonuclease and endonuclease enzymes are active at $\mathrm{pH} 5$ and 6 , but not at $\mathrm{pH} 9$. This observation is similar to that reported for extracellular nuclease isolated from tobacco cultured cells. ${ }^{22)}$

It was reported that cultured tobacco cells release endonuclease into the medium. ${ }^{22)} \mathrm{We}$ detected that both types of nuclease activity were associated with cells or protoplasts from Datura innoxia suspension culture. They were not excreted or release from cells or protoplasts because there was no nuclease in the supernatant of cells or protoplasts filtered through $0.45 \mu \mathrm{m}$ Millipore filters (data not shown). It was also ruled out that the exonuclease activity of protoplasts is due to residual nuclease contamination of the enzymes used for preparation of protoplasts (Fig. 2, column 9 ). Therefore, exonucleases associated with the protoplasts were exposed when the cell wall is removed by enzymatic digestion.

The mechanism of transfer of the Ti plasmid from the bacteria to plant cells in spite of the presence of nucleases ${ }^{13)}$ still remains unknown. Other factors from bacterial cells might protect the $\mathrm{Ti}$ plasmid from degradation when infected into plants. The mechanism of tumor induction is not yet known. It is interesting to note that the cultured cells from monocotyledonous plants, in which tumores are rarely induced by $A$. tumefaciens, ${ }^{23)}$ have exonuclease activity whereas cells from most dicotyledonous plants do not. However, there is no proof for a direct relationship.

Acknowledgment. The authors thank Dr. L. R. Wetter and Dr. L. C. Fowke for critical reading of this manuscript. The authors also thank Mr. D. Horn for his excellent technical assistance.

\section{REFERENCES}

1) D. Hess, Naturwissenschaften, 59, 348 (1972).

2) L. Ledoux, R. Huart and H. Jacobs, Nature, 249, 17 (1974).

3) P. F. Lurquin and Y. Hotta, Plant Science Letters, 5, 103 (1975).

4) A. Kleinhofs, F. C. Eden, M-D. Chilton and A. J. 
Bendich, Proc. Natl. Acad. Sci. USA, 72, 2748 (1975).

5) K. Ohyama, O. L. Gamborg and R. A. Miller, Can. J. Bot., 50, 2077 (1972).

6) F. Hoffmann and D. Hess, Z. Pflanzenphysiol., 69, 81 (1973).

7) A. J. Bendich and P. Filner, Mutation Res., 13, 199 (1971).

8) Y. Hotta and H. Stern, "Informative Molecules in Biological Systems," ed. by L. G. H. Ledoux, NorthHolland, Amsterdam, 1971, p. 176.

9) R. B. Meager, "Genetic Engineering for Nitrogen Fixation," ed. by Hollaender, Plenum Press, New York, 1977, p. 129.

10) P. F. Lurquin and C. I. Kado, Molec. Gen. Genet., 154, 113 (1977).

11) B. Watson, T. C. Currier, M. P. Gordon, M-D. Chilton and E. W. Nester, J. of Bacteriol., 123, 255 (1975).

12) I. Zaenen, N. van Larebeke, H. Teuchy, M. van Montagu and J. Schell, J. Mol. Biol., 86, 109 (1974).

13) M-D. Chilton, M. H. Drummond, D. J. Merlo, D. Sciaky, A. L. Montoya, M. P. Gordon and E. W. Nester, Cell, 11, 263 (1977).

14) M. Suzuki and I. Takebe, Z. Pflanzenphysiol., 89,
297 (1978).

15) B. G. Hughes, F. G. White and M. A. Smith, $Z$. Pflanzenphysiol, 87, 1 (1978).

16) K. Ohyama, L. E. Pelcher and A. Schaefer, "Frontiers of Plant Tissue Culture 1978," ed. by T.

A. Thorpe, The International Assoc. for Plant Tissue Culture, Calgary, 1978, p. 75.

17) O. L. Gamborg, "Plant Tissue Culture Methods," eds. by O. L. Gamborg and L. R. Wetter, NRCC, Saskatoon,1975, p. 1.

18) K. Ohyama, L. E. Pelcher, A. Schaefer and L. C. Fowke, Plant Physiol., 63, 382 (1979).

19) T. Eriksson, Physiol. Plant, 18, 976 (1965).

20) F. Constable, "Plant Tissue Culture Methods," eds. by O. L. Gamborg and L. R. Wetter, NRCC, Saskatoon, 1975, p. 11.

21) A. M. Ledeboer, A. J. M. Krol, J. J. M. Dons, F. Spier, R. A. Schilperoort, I. Zaenen, N. van Larebeke and J. Schell, Nucleic Acids Res., 3, 449 (1976).

22) A. E. Oleson, A. M. Janski and E. T. Clark, Biochim. Biophys. Acta, 366, 89 (1974).

23) J. A. Lippincott and B. B. Lippincott, Ann. Rev. Microbiol., 29, 377 (1975). 